\title{
Use of chlorine solutions as disinfectant agents in health units to contain the spread of COVID-19
}

\section{Uso de soluções de cloro ativo como agente desinfetante em unidades de saúde para conter a propagação do COVID-19}

\author{
Frank Pereira de Andrade ${ }^{1}\left(\mathbb{D}\right.$, Camila de Bessa Pereira $^{2}$ (1) \\ 1. Professor of the Pharmacy Course at Federal University of São João del-Rei, Divinópolis, MG - Brazil. 2. Student of the Pharmacy Course at Federal \\ University of São João del-Rei, Divinópolis, MG - Brazil.
}

\begin{abstract}
Objective: This study aimed to gather information available in different disinfection protocols for establishments that provide care to suspected or confirmed patients with COVID-19, to contain the spread of the virus, besides proposing different ways of preparing the bleach solution for the most varied purposes within a Health Unit. Methods: It was realized bibliographic research about disinfection protocols to contain COVID-19, as well as disinfectant agents used to inactivate the virus. Results: Many hospitals and basic health units perform disinfection in many hospitals based on disinfection protocols that are not suitable due to the insufficient amount of daily cleaning recommended, as well as the use of ineffective agents or in inadequate concentrations. Among the most used disinfectant agents chlorine solutions have been described as the most efficient and most applicable, thus, we recommend the use of solutions containing chlorine in its composition, such as commercial bleach, as well as highlight its finalities, correct way of use and application at environments that take care of patients with disease COVID-19 or suspected. Conclusion: the use of solutions containing chlorine in its composition, such as commercial bleach, is a viable alternative for disinfecting hospitals and health basic units, due to its efficiency against the coronavirus, low cost, accessibility, and greater applicability when detected by other widespread disinfectant agents.
\end{abstract}

Keywords: COVID-19. Hospital disinfection. Disinfection protocols. Disinfecting agents. Chlorine solutions.

\begin{abstract}
Resumo
Objetivo: Este trabalho teve como objetivo reunir informações disponíveis em diferentes protocolos de desinfecção para estabelecimentos que prestam atendimento a pacientes suspeitos ou confirmados com COVID-19, para conter a disseminação do vírus, além de propor diferentes formas de preparo da solução de água sanitária para as mais variadas finalidades dentro de uma Unidade de saúde. Métodos: foi realizada uma pesquisa bibliográfica sobre protocolos de desinfecção para conter o COVID-19, bem como os agentes desinfetantes empregados para inativar o vírus. Resultados: Muitos hospitais e unidades básicas de saúde realizam a desinfecção baseada em protocolos que não são adequados devida a quantidade insuficiente de limpeza diária recomendada, bem como o uso de agentes ineficazes ou em concentrações inadequadas. Dentre os agentes desinfetantes mais utilizados, soluções de cloro ativo têm sido descritas como as mais eficientes e aplicáveis, portanto, recomendamos o uso de soluções contendo cloro ativo em sua composição, como água sanitária, bem como enfatizamos suas finalidades, correta forma de uso e apliações em ambientes que prestam cuidados a pacientes suspeitos ou confirmados com COVID-19. Conclusão: o uso de soluções contendo cloro ativo em sua composição, como água sanitária, é uma alternativa viável para desinfecção de hospitais e unidades básicas de saúde devido a sua eficácia contra o coronavírus, baixo custo, fácil acesso, e maior aplicabilidade quando comparados com outros agentes desinfetantes.ts.
\end{abstract}

Palavras-chave: COVID-19. Desinfecção hospitalar. Protocolos de desinfecção. Agentes desinfetantes. Soluções de cloro ativo.

\section{INTRODUCTION}

The Coronaviruses are enveloped viruses, with positive singlestranded RNA genome, belonging to the family Coronaviridae and subfamily Coronavirinae that can cause respiratory and intestinal infection in animal and humans ${ }^{1,2}$. There are known six human coronaviruses HCoV-229E, HCoV-NL63, HCoV-OC43, HCoV-HKU1, SARS-CoV (severe acute respiratory syndrome coronavirus) and MERS-CoV (Middle East respiratory syndrome coronavirus). Among them stand out SARS-CoV and MERS$\mathrm{CoV}$, considered highly pathogenic and responsible for causing outbreaks in China and the Middle East, respectively ${ }^{3}$.

At December 2019, a new type of coronavirus capable of infecting humans, named by International Committee on Taxonomy of Viruses as severe acute respiratory syndrome coronavirus 2 (SARS-CoV-2), was responsible for an outbreak of coronavirus disease 2019 (COVID-19), in Wuhan, China, and quickly spread across the world ${ }^{4}$. The COVID-19 disease is characterized by fever, tiredness, dry, cough, pains sore throat, 
difficulty breathing and less common diarrhea, nausea, runny nose, and in severe cases acute respiratory distress syndrome (ARDS) ${ }^{5}$. According to the World Health Organization (WHO), until 24 April 2020, there are 2626321 confirmed cases and 181938 confirmed deaths, in countries, areas, or territories with cases of COVID $19^{6}$.

The main mode of transmission of SARS-CoV-2 is directly, from person to person through contact with the respiratory droplets of an infected person. But, the indirect form through contact with contaminated surfaces in the immediate environment and/or objects used by the infected person also is described as a possibility ${ }^{7,8}$. The spread of SARS-CoV-2 by indirect route is not yet fully established, like for some respiratory viruses, but some shreds of evidence have been described.

Although it cannot be used to determine whether transmission occurred from contaminated surfaces, the SARS-CoV-2 RNA was identified on surfaces of cabins of Cruise Ships up to 17 days after cabins were vacated ${ }^{9}$. In a review about the transmission of SARS and MERS coronaviruses and influenza virus through dry surface contaminated, the authors founded that when compared with others human coronaviruses, SARS-CoV and MERS-CoV can survive on dry surfaces, being that SARS-CoV can survive for more than six days when dried on to Petri dishes ${ }^{10}$. And Kampf, Todt, Pfaender e Steinmann (2020) report that human coronavirus can remain on surfaces for up to 9 days ${ }^{11}$.

Hospitals and basic health units receive a large flow of people daily, whether or not they have coronavirus infection. An infected person can contaminate the environment, and since the virus can remain in environments and surfaces for a significant period, these establishments can indirectly contribute to the spread of viruses. In this sense, it is necessary to adopt infection prevention and control measures in these Health Units (HU) to contain the spread of COVID-19 and thus guarantee the health of health agents and patients. Although the indirect transmission is uncertain, the cleaning and decontamination of environments is essential to prevent the spread of viruses and has been recommended by $\mathrm{WHO}$ as a measure of prevention and control of the outbreak ${ }^{7}$. The realization of screening and infrared temperature, the use of masks for all staff, the installation of rapid disinfectant stations for hand hygiene and disinfection in outpatient clinics before and after each patient's care, as well as the disinfection of medical equipment such as stethoscopes, thermometers, sphygmomanometers, are effective measures that have contributed to decreasing infectivity in non-isolated areas adopted by hospitals in China ${ }^{12}$.

In this sense, it is suggested that surfaces frequently touched, such as door handles, bedding, tables, light switches, and others, be disinfected ${ }^{13}$, especially in areas subject to a higher viral load. Therefore, it is necessary to create effective and economical disinfection measures for hospital environments and other health units as a strategy to contain the transmission of the COVID-19 virus. Some health units, in emerging countries like Brazil, adopt disinfection measures for containment made available by regulatory agencies ${ }^{14}$ that are unsuitable for SARS-
CoV-2 due to the low frequency recommended by $\mathrm{WHO}^{15,16}$, as well as the use of sanitizing agents with ineffective active ingredient and concentrations ${ }^{11,16,17}$. Given the above, this review aimed to gather as information available in different health disinfection protocols for establishments that provide care to suspected or confirmed patients of COVID-19, to prevent the spread of viruses, as well as propose the application of correct use of different effective disinfectant agents and their purposes, including your application for health units.

\section{METHODS}

A search was carried out on PubMed at 15 April 2020, with the following terms, always in combination with "coronavirus", "MERS-CoV", "SARS-CoV", "SARS-CoV-2 or "COVID-19": protocols disinfection (2/0/0/0/3 occurrences), chemical inactivation (4/3/5/2/2 occurrences), disinfection (48/6/14/29/47 occurrences) and hospitals disinfection (22/2/8/13/23 occurrences), considering the period of November 1, 2019, to April 15, 2020. Only publications that effectively presented information and foundations necessary for the elaboration of this work were included. Original data about MERS-CoV, SARS-CoV, and SARS-CoV-2 were not obtained in disinfection protocols. Also, different disinfection protocols ${ }^{15-22}$ were inserted to consolidate the information about the agents and their purposes.

\section{RESULTS AND DISCUSSION}

The sodium hypochlorite $(\mathrm{NaClO})$, present in chlorine solutions (active chlorine), is one of the most relevant and predominant disinfectants for surface disinfection, against COVID-19. Some recent works suggest a $\mathrm{NaClO}$ concentration of 0.1 to $0.5 \%$ to promote inactivation of coronavirus in $4 \log _{10}$ or more, on inanimate surfaces, and a minimum concentration of $0.21 \%$ to promote the reduction of viral infectivity $>3 \log _{10}$ on surfaces with suspended material ${ }^{11,23,24}$. Recently, Kindermann, Karbiener, Leydold, Knotzer, Modrof, and Kreil (2020) evaluated an inactivation of three viruses involved in lipids, using solutions with free chlorine from 0.45 to $0.65 \%$. The authors reported inactivation of three investigated viruses, with a reduction factor $>4 \log _{10}$, and suggest that the disinfection of suspensions and surfaces based on $\mathrm{ClO}^{-}$, or chlorine, may be considered effective $^{25}$. It must be considered, however, that the presence of organic matter on the surface may decrease, or even to annul, the virucidal activity of a hypochlorite solution 26 . In this sense, it is recommended to clean the surfaces before disinfection. Finally, it should be noted that solutions with increased sodium hypochlorite are corrosive, irritating mucous membranes, eyes, and $\operatorname{skin}^{26}$.

Another disinfecting agent commonly cited for inactivating COVID-19 is ethyl and propyl alcohol. It's possible to reduce coronavirus infection by $4 \log _{10}$ or more, using ethanol (78 to $95 \%$ ) or 2-propanol (70 to $100 \%$ ) on surfaces with suspended material. Also is possible to obtain a log10 reduction factor of 2 to 4 in the infectivity when employing lower concentrations 
of ethyl alcohol (62 to 71\%), with exposure of $1 \mathrm{~min}^{11,24}$. Li et al (2020), for example, recommends the use of $75 \%$ alcohol for disinfecting tables in the wards27. The comparison between virucidal activity against enveloped viruses, including SARSCoV and MERS-CoV of 2 alcohol-based formulations published by WHO against enveloped viruses, including SARS-CoV and MERS-CoV demonstrated that for CoVs, the WHO formulation II at a concentration of $30 \%$ was able to inactivate the virus, while WHO formulation I required a higher concentration $(\geq 40 \%)$. Besides, both formulations inactivated the viruses with 30 seconds of exposure, reinforcing that these solutions can be used in cases of outbreaks ${ }^{28}$.

It is important to highlight that the use of ethyl alcohol has been highly recommended for disinfection hands ${ }^{27,29-34}$, leading to a reduction in the spread of the pathogen.

A third disinfecting agent cited for inactivation of COVID-19 on inanimate surfaces is povidone-iodine (PVP-I; C6H9I2NO) ${ }^{11}$. Formulations based on povidone, widely used as disinfectants for hands, skin, and mucous membranes, have high antiviral and antibacterial activity and, due to their safety, tolerability and accessibility, are widely used for the spread of infectious diseases. This iodophor substance is effective for a wide range of enveloped and non-enveloped viruses ${ }^{35}$. At concentrations of 0.23 to $7.5 \%$ can promote a reduction of coronavirus infectivity in $4 \log 10$ or more ${ }^{11,23}$. When evaluating the antiviral activity of 5 products based on PVP-I against SARS-CoV, Kariwa, Fujii, Takashima (2006) note that the treatment completely inactivated the virus with just 2 minutes of contact with the products36. Eggers, Eickmann, Zorn (2015) evaluated the in vitro efficacy of 3 products based on PVP-I against MERS-CoV, in concentrations of $1 \%, 4 \%$, and $7.5 \%$, and the title viral was reduced by a factor $\geq 10^{4}$, at room temperature, in clean and dirty conditions, with the only contact of 15 seconds, using diluted (1:10) and undiluted solutions. The data obtained are following studies that demonstrate good PVP-I viral activity for enveloped viruses ${ }^{37}$. Geller, Varbanov, and Duval (2012) studied the sensitivity of some enveloped and non-enveloped viruses to some antiseptic/disinfectant formulations. The results obtained show the use of povidone-iodine at concentrations of $10 \%$ (with $1 \%$ iodine available), after 1 minute of contact is effective to promote a reduction of viral titre in $\geq 3 \log _{10}$ for human coronavirus (HCoV 229E) ${ }^{38}$.

Finally, the last disinfecting agent widely used for COVID-19 inactivation on inanimate surfaces is hydrogen peroxide, which at a concentration of $0.5 \%$ promotes the reduction of $10^{4}$ of COVID-19 infectivity, with only 1 minute of exposure ${ }^{11,23}$. Goyal, Chander, Yezli, and Otter (2014) evaluated the virucidal efficacy in vitro, employing hydrogen peroxide vapor in a condensation system, against 3 enveloped RNA virus, among them, the SARSCoV. For the 3 volumes of hydrogen peroxide $(25,27$ and 33 $\mathrm{mL})$, the authors achieved a virucidal inactivation greater than $3,8 \log _{10}$ for the three viruses evaluated ${ }^{39}$.

Tuladhar, Terpstra, Koopmans, and Duizer (2012) evaluated the effectiveness of hydrogen peroxide vapor against enteric and respiratory viruses. The experiments were carried out with the average concentration of hydrogen in 126 and $127 \mathrm{mg} \mathrm{L}^{-1}$, for $1 \mathrm{~h}$ in a $1.5 \mathrm{~m}^{3}$ isolator and obtained a good viral effect of disinfection with hydrogen peroxide vapor, for all viruses tested, at a concentration of $120 \mathrm{mg} \mathrm{L}^{-1} 40$. Chandy, Nasir, Srinivasan, Klass, Nicolaou, Babu (2020) suggest that critical materials, such as endovascular or endovaginal ultrasound probes and reusable surgical instruments, should be disinfected with hydrogen peroxide vapor ${ }^{29}$. The efficiency of ionized hydrogen peroxide (IHP) $\left(7.8 \% \mathrm{H}_{2} \mathrm{O}_{2}\right.$ solution) also was evaluated for the disinfection of $\mathrm{N} 95$ respirators. For this purpose, $\mathrm{N} 95$ respirators were inoculated with three different concentrations of influenza A virus (enveloped RNA virus with some similar virological characteristics as coronaviruses) and IHP was sprayed three times during 6 seconds. One hour after, the culture viral was done, and the findings demonstrated by the IHP are capable of killing the virus at moderate to high levels of inoculums ${ }^{41}$.

Rowan and Laffy (2020) draw attention to the possibility of the presence of organic matter in affecting the nature of the oxidizing process of vaporized hydrogen peroxide, as well as about the preliminary cleaning process representing a problem in Health Units due to proportional need to decontaminate the equipment used in this process for COVID-19. The authors reported the use of a chlorine solution, called Actichlorplus, in the procedures for washing and disinfecting equipment such as air-purifying respirators after exposure to coronavirus, as well as reprocessing covers used by COVID19 patients in an intensive care unit (IUC), reinforcing the applicability and viability of solutions containing chlorine to contain the virus in $\mathrm{HU}^{42}$.

Other disinfectant agents such as glutardialdehyde (0.5 to $2.5 \%$ ), formaldehyde $(0.009$ to $1 \%)$, benzalkonium chloride $(0.05 \%)$ and Didecyl dimethyl ammonium chloride $(0.0025 \%)$ presented a virucidal inactivation $\geq 3 \log _{10}$. The agent Chlorhexidine digluconate was ineffective ${ }^{11}$. Since these reagents are not widely cited in well-established disinfection protocols ${ }^{15-22}$, they will be disregarded in the elaboration of a proposal for the application of effective disinfectant agents in containing COVID- 19. In this sense, we will suggest different disinfection applications with the most common disinfecting agents: $\mathrm{NaClO}, \mathrm{CH}_{3} \mathrm{CH}_{2} \mathrm{OH}, \mathrm{C}_{6} \mathrm{H}_{9} \mathrm{I} 2 \mathrm{NO}$ and $\mathrm{H}_{2} \mathrm{O}_{2}$. These applications are a compilation of all protocols available in the literature.

The disinfection of environments that provide care to suspected and confirmed COVID-19 patients deserve special attention to contain the spread of the virus and due to the high exposure of patients and health agents themselves. These environments can be classified as low, medium, and high risk. Yang, Soh, Cai, Peng, Zhang, Guo (2020) reported that in the Department of Oral and Maxillofacial Surgery of Peking University School and Hospital of Stomatology, the disinfections are carried out as follows:

(i) Low-risk areas - disinfection with detergent and water for cleaning. It should be performed 1 or 2 times a day. Included in this classification are facilities not accessible to patients, such as doctors and nurses' rooms. 
(ii) Medium risk areas - disinfection with $500 \mathrm{mg}$ $\mathrm{L}^{-1}$ chlorine solution, with minimum contact of 30 minutes, followed by cleaning with water. It should be performed 1 or 2 times a day. This classification includes areas accessible to normal and stable patients, such as wards and medical offices.

(iii) High-risk areas - disinfection with $500 \mathrm{mg} \mathrm{L}^{-1}$ chlorine solution, with minimum contact of 30 minutes, followed by cleaning with water. It should be performed 2 or more times a day. This classification includes infected or contaminated areas, as well as isolation areas for patients with high susceptibilities, such as operating rooms, ICU, post-anesthetic care units, and others. Disinfection is recommended after each clinical procedure ${ }^{42}$.

Gou, Yin, Xiong, Peng, Li, Wu (2020) reported about protective measures applied in the wards of the Pancreatic Surgery Department, Peking Union Medical College Hospital, Tongji Medical College, Huazhong University of Science and Technology. The floors of these wards were disinfected twice a day, with a solution containing $1000 \mathrm{mg} \mathrm{L}^{-1}$ of chlorine. The surfaces on which patients had frequent contact were also disinfected with this chlorine solution, while medical instruments and equipment, as term meters, stethoscopes and sphygmomanometers were cleaned and disinfected twice a day with $75 \%$ ethanol ${ }^{44}$.

Sleep monitoring experts [45] recommend that hospital rooms designed for sleep monitoring be disinfected twice a day, using $2000 \mathrm{mg} \mathrm{L}^{-1}$ solution, and that some equipment such as metal electrodes and sensors metal (tin plate electrodes and button electrodes) are disinfected with $1000 \mathrm{mg}$ L-1 solution, while materials such as mask, pipeline, headband, and heated humidifier are disinfected with $75 \%$ ethanol ${ }^{45}$.

Xu et al (2020) reported several preventive measures to control the coronavirus epidemic in non-isolated areas of a hospital. Among the measures, the authors reported that surfaces such as beds, treatment tables and chairs, treatment carts, and others, as well as floors, were cleaned and disinfected with a chlorine solution at $1000 \mathrm{mg} \mathrm{L}^{-1}$, every 4 hours ${ }^{12}$.

When reporting on protective measures for patients with COVID-19 pneumonia at the National Center for Disease Control and Prevention in China, the authors suggest that surfaces such as public tables and chairs, public door and window handles, public bathrooms and washbasins should be disinfected with $500 \mathrm{mg} \mathrm{L}^{-1}$ chlorine solution. They also suggest that household waste should be sent to a separate trash can and cleaned daily, or whenever necessary. However, before cleaning, you should spray or sprinkle a 500 to $1000 \mathrm{mg} \mathrm{L}^{-1}$ chlorine solution on the garbage, so that the entire contents are completely moist. Only after 30 minutes of contact, the garbage must be sent to a suitable storage place for hospital waste. Finally, the authors reported daily disinfection of the surgical tables, using a 1000 $\mathrm{mg} \mathrm{L}^{-1}$ chlorine solution ${ }^{46}$.
Zheng et al (2020) when addressing an Emergency Plan for inter-hospital transfer of newborns with SARS-CoV-2 infection suggest that disinfections be carried out in ambulances, equipment used in the transfer and protective equipment. The authors make the following recommendations:

(i) Car air - disinfection with $1.3 \%$ to $5 \%$ hydrogen peroxide solution, in aerosol form, with a flow of approximately $20 \mathrm{~mL} \mathrm{~m}^{-3}$. After 1 hour, the windows must be opened for ventilation.

(ii) Ambulance surfaces - disinfection with a solution containing $1000 \mathrm{mg} \mathrm{L}^{-1}$ of chlorine. Wipes are moistened in this solution to rub stretchers, handrails, ambulance floors, and other surfaces present. If there are contaminants on the surfaces, such as blood, body fluids, excrement, and others, it must be removed before disinfection. After 1 hour, the windows must be opened for ventilation, and the surfaces must be cleaned. First aid kits, external and external ECG monitors, and booths, must be disinfected with $75 \%$ alcohol. Finally, the filter or filter material of the filtering and sterilization system of the negative pressure ambulance must be disinfected with the indicated solution of $2000 \mathrm{mg} \mathrm{L}^{-1}$ of chlorine. The contact must be for two hours.

(iii) Transfer equipment - disinfection with a solution containing $2000 \mathrm{mg} \mathrm{L}^{-1}$ of chlorine. Items such as breathing apparatus, first aid box, monitor, intravenous infusion pump, oxygen cylinder, laryngoscope cable are part of this context.

(iv) Protective equipment - disinfection with a solution containing $2000 \mathrm{mg} \mathrm{L}^{-1}$ of chlorine. Items such as clothing, gloves, shoe covers, face mask, glasses, and others are part of this context ${ }^{47}$.

There is an expectation that the Health Units that provide care to COVID-19 perform disinfection procedures, in compliance with the regulations of establishments and regulatory bodies. It is noted that establishments that managed to promote a significant reduction in the infectivity of the virus used chlorine solutions in almost all disinfection procedures. However, it is observed that there is no consensus on the concentrations of the disinfectant agent according to different purposes. In this sense, a review on the subject is necessary, based on the recommendations of recognized regulatory bodies, such as World Health Organization, Centers for Disease Control and Prevention (such as American, Chinese and European) and others, so that there is an effective reduction in the transmission of the virus through disinfection of surfaces in Health Units, employing chlorine solutions, and may even extend to other environments.

Given the above, we present in Table 1, the different applications of chlorine solutions mentioned in the protocols ${ }^{15,16,18-22}$ and we recommend other applications, perhaps missing from the 
protocols, but that would be well suited. Also, we recommend the frequency of disinfection for some purposes. The suggested recommendations were based on the experiences described in the references used to prepare this work. Finally, at the end of the table, we add the applications mentioned in the protocols for alcohol and iodized povidone.

Table 1. Disinfecting agents recommended and their applicability.

\section{Sodium hypochlorite and other chlorine-based agents}

\begin{tabular}{|c|c|c|}
\hline Agent & Applicability & Action \\
\hline \multirow{2}{*}{ Chlorine $20000 \mathrm{mg} \mathrm{L}^{-1}$ or $2 \%$} & Patients' secretions and vomiting & $\begin{array}{l}\text { Collect the material in a container, add the } \\
\text { disinfectant so that it has twice the volume of } \\
\text { substance to be treated and keep in contact for at } \\
\text { least two hours. After removing the contaminants, } \\
\text { decontaminate the containers with } 5000 \mathrm{mg} L-1 \\
\text { free chlorine solution, with a contact time of } 30 \\
\text { minutes }^{21}\end{array}$ \\
\hline & Faeces and other excrement ${ }^{2}$. & $\begin{array}{l}\text { Collect the material, add the disinfectant so that } \\
\text { it has twice the volume to be treated and leave } \\
\text { in contact for } 2 \text { hours. For large volumes of liquid } \\
\text { excrement, add powdered disinfectant, containing } \\
70 \text { to } 80 \% \text { chlorine, with a } 20: 1 \text { ratio (excrement: } \\
\text { disinfectant agent) and keep in contact, under } \\
\text { agitation, for } 2 \text { hours }{ }^{21} \text {. }\end{array}$ \\
\hline
\end{tabular}

Towels and other tissues used to clean contaminants such as blood, vomiting and other patients' secretions.

Chlorine 5000 to $10000 \mathrm{mg} \mathrm{L}^{-1}$ or $0.5 \%$ to $1 \%$

Chlorine 3000 to $5000 \mathrm{mg} \mathrm{L}^{-1}$ or $0.3 \%$ to $0.5 \%$

Discard of dead bodies ${ }^{3}$.

Frequently touched objects, such as light switches, door handles, bed rails, bedside tables, telephones and others

Chlorine $5000 \mathrm{mg} \mathrm{L}^{-1}$ or $0.5 \%$

Bathrooms and latrines ${ }^{4}$. We recommend including other containers for collecting feces.

Floors and walls from health units that provide care to patients, without dirt with the naked eye ${ }^{6}$.

Chlorine $1000 \mathrm{mg} \mathrm{L}^{-1}$ or $0.1 \%$
Surfaces of medical facilities, fences, bedside cabinets, furniture, door handles, household items and others? ${ }^{7}$.

Solid non-porous surfaces from other establishments that are not health unities, such as houses.
Leave in contact for at least 30 minutes with the disinfectant solution.

Dip an absorbent material (towel) in the disinfectant solution and promote the removal of pollutants 21 . We recommend disinfecting each patient change.

Immerse cotton balls or gauze in the disinfectant solution and fill the patient's mouth, ears, nostrils, anus, tracheostomy and other open channels ${ }^{21}$.

Remove visible dirt and apply disinfectant. Perform the procedure twice and when necessary ${ }^{15}$.

Remove as visible dirt and apply disinfectant. Perform the procedure at least 2 times and when necessary ${ }^{15}$.

Dispose of as fraud, or contents of the latrines or container used in the bathroom or in the separate latrine ${ }^{5}$.

After removing feces, clean with mild detergent and water, apply disinfectant and rinse with clean water. Discard the rinse water in a bottle or toilet bowl ${ }^{18}$.

Spray from the inside out with a spray flow of 100 $\mathrm{mL} \mathrm{m}-2$ to $300 \mathrm{~mL} \mathrm{~m} \mathrm{~m}^{-2}$ and a minimum time of 30 minutes ${ }^{21}$.

We recommend performing the procedure twice and when necessary

Remove visible contaminants and apply disinfectant. After 30 minutes of contact, clean with water ${ }^{21}$.

We recommend performing the procedure twice and when necessary.

Wash with detergent or soap and apply the disinfectant for at least 1 minute ${ }^{19}$. 
Bed linen for inpatients, with visible contaminants. We recommend including clothing and other clothing items with contaminants visible from patients.

Chlorine $500 \mathrm{mg} \mathrm{L}^{-1}$ or $0.05 \%$

Bed linen for inpatients, without visible contaminants. We recommend including clothing and other clothing items with no visible contaminants from patients.

$\begin{array}{ll}\text { Chlorine }>40 \mathrm{mg} \mathrm{L}^{-1} \text { or } \geq 0.004 \% & \quad \text { Independent septic tanks } \\ & \begin{array}{l}\text { Medical assistance areas (patient rooms, waiting } \\ \text { rooms, procedure rooms, resuscitation rooms and } \\ \text { others) }\end{array}\end{array}$

\begin{tabular}{ll} 
Hypochlorite $0.1 \%$ & $\begin{array}{l}\text { Bathrooms, washbasins and sanitary facilities } \\
\text { present in the areas of medical assistance } \\
\text { (patient rooms, waiting rooms, procedure rooms, } \\
\text { resuscitation rooms and others). } \\
\text { Ventilation systems pipes. }\end{array}$ \\
\hline Agent & EthylAlcohol \\
\hline
\end{tabular}

Alcohol 75\%

Hand hygiene.

Objects that should be unique for each patient

(stethoscope, blood pressure meters and Apply the alcoholic solution before each patient ${ }^{16}$. thermometers).

Alcohol $70 \%$
Wash with warm water $\left(60{ }^{\circ} \mathrm{C}\right.$ to $\left.90{ }^{\circ} \mathrm{C}\right)$ with detergent and apply the disinfectant for 30 minutes ${ }^{15}$.

Dip the bedding in the disinfectant. After 30 minutes, wash in the washing machines, keeping the chlorine concentration constant at $500 \mathrm{mg} \mathrm{L}^{-121}$.

Apply the disinfectant regularly and maintain a minimum contact of 1.5 hours. Ensure that the residual chlorine reaches a concentration of $10 \mathrm{mg}$ $\mathrm{L}^{-121}$.

Wash with detergent or soap and apply disinfectant ${ }^{19}$.

We recommend performing the procedure twice and when necessary.

Wash with detergent or soap and apply disinfectant19.

We recommend performing the procedure twice and when necessary.

Apply the disinfectant ${ }^{52}$

\section{Action}

Apply the alcoholic solution for 20 seconds $^{15,20}$. If there are visible dirt, wash with running water and soap and apply the disinfectant ${ }^{21}$.

Remove dirt visible to the naked eye and apply the alcoholic solution ${ }^{20}$.
Electronic materials such as cell phones, tablets, touch screens, remote controls and keyboards.

\section{lodophores (Povidone lodine and others)}

\begin{tabular}{lll}
\hline Agent & Applicability & Action \\
\hline Povidone iodine $0.5 \%$ & Contaminated skin ${ }^{10}$. & $\begin{array}{l}\text { Remove contaminants, apply disinfectant with } \\
\text { disposable absorbent material for more than } 3 \\
\text { minutes and wash with clean wate }{ }^{21} .\end{array}$ \\
Povidone iodine $0.05 \%$ & Mucosas. & $\begin{array}{l}\text { Wash the mucosa, rinse and apply the iodophor } \\
\text { solution }{ }^{21} .\end{array}$ \\
\hline
\end{tabular}

1 Example: If the amount of secretion and/or vomit is 1 liter, 2 liters of disinfectant with a free chlorine concentration of $20000 \mathrm{mg} \mathrm{L}^{-1}$ should be added.

2 The solution used can be replaced with a peracetic acid $\left(\mathrm{C}_{2} \mathrm{H}_{4} \mathrm{O}_{3}\right)$ solution with a concentration of $500 \mathrm{mg} \mathrm{L}^{-1}$ to $2000 \mathrm{mg} \mathrm{L}^{-1}$.

3 The solution used can be replaced with a $0.5 \%$ peracetic acid $\left(\mathrm{C}_{2} \mathrm{H}_{4} \mathrm{O}_{3}\right)$ solution.

$4 \mathrm{WHO}, 2020$ [15] recommends that each patient be provided with his own toilet or latrine, so that there is a door that closes to separate him from the room

5 Toilets and latrines used only by suspected or confirmed COVID-19 patients. The World Health Organization, feces must be treated as a biological risk, thus meeting all handling recommendations [18].

6 The solution used can be replaced with a $500 \mathrm{mg} \mathrm{L}^{-1} \mathrm{chlorine}$ dioxide $\left(\mathrm{ClO}_{2}\right)$ solution.

7 The solution used can be replaced with a $500 \mathrm{mg} \mathrm{L}^{-1} \mathrm{chlorine}$ dioxide $\left(\mathrm{ClO}_{2}\right)$ solution.

8 For surfaces incompatible with sodium, the hypochlorite solution should be replaced with an ethanol solution, with a minimum concentration of $70 \%$, after cleaning with a neutral detergent. In addition, the solution used can be replaced with $70 \%$ ethyl alcohol solution.

9 The solution used can be replaced with supplies based on $60 \%$ ethyl alcohol.

10 A solution used can be replaced by a $75 \%$ ethyl alcohol solution.

It can be seen that solutions containing chlorine have the greatest applicability for disinfecting surfaces present in places of care for suspected or confirmed patients for COVID-19, and can also be extended to other places, such as homes, means of transportation in general, schools, supermarkets, etc. Thus, we recommend the use of household bleach, since it has chlorine and sodium hypochlorite in its constitution.
Besides, this household bleach, like alcohol, is widely available in many countries and is cheaper than other disinfectants recommended by WHO and other authors ${ }^{48,49}$ such as phenolic compounds, quaternary ammonium, hydrogen peroxide, orthophthaladehyde, glutaraldehyde, formaldehyde and peracetic acid. 
A NaClO solution, such as bleach, is represented by the dynamic equilibrium represented in equation 1 , and its mechanism of action is the set of actions represented by the following responses 2 to $4^{50}$.

\section{Equation 1}

$\mathrm{NaOCl}+\mathrm{H}_{2} \mathrm{O} \rightleftharpoons \mathrm{NaOH}+\mathrm{HOCl} \rightleftharpoons \mathrm{Na}^{+}+\mathrm{OH}^{-}+\mathrm{H}^{+}+\mathrm{OCl}^{-}$

\section{Equation 2}

$\begin{aligned} & \mathrm{R}(\mathrm{COO}) \mathrm{R} \\ & \text { Fattyacid } \\ & \substack{\text { Sodium } \\ \text { Hydroxide }}\end{aligned} \underset{\text { Soap }}{\mathrm{NaOH}(\mathrm{COO}) \mathrm{Na}}+\underset{\text { Glycerol }}{\mathrm{ROH}}$

\section{Equation 3}

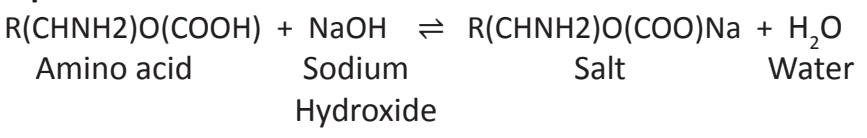

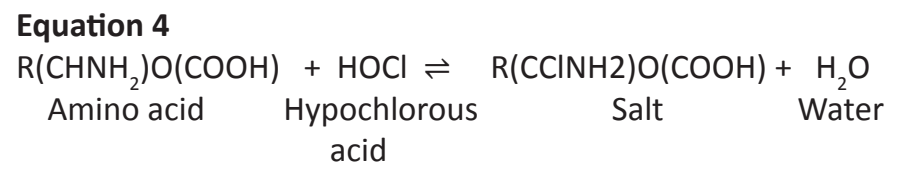

It should be noted that the reaction presented in equation 1 is best represented by equation 5 below since there are no $\mathrm{H}^{+}$ species in solution.

$$
\mathrm{NaOCl}+\mathrm{H}_{2} \mathrm{O} \rightleftharpoons \mathrm{NaOH}+\mathrm{HOCl} \stackrel{\mathrm{H}_{2} \mathrm{O}}{\rightleftharpoons} \mathrm{Na}^{+}+\mathrm{OH}^{-}+\mathrm{H}_{3} \mathrm{O}^{+}+\mathrm{OCl}^{-}
$$

It is observed in equation 2 that sodium hypochlorite acts as a lipophilic organic solvent, promoting the degradation of fatty acids, transforming them into salts of fatty acids (soap) and glycerol (alcohol), and reducing the surface tension of the remaining solution. In reaction 3 , it can be observed that the amino acids are neutralized by sodium hypochlorite, leading to the formation of salt and water. Finally, with the exit of hydroxyl ions, the $\mathrm{pH}$ of the reaction medium decreases and the hypochlorous acid, present in the sodium hypochlorite solution, acts as a solvent when in contact with the organic tissue, releasing chlorine which, combined with the amino protein group, promotes the formation of chloramines (Equation 4). Thus, it can be said that hypochlorous acid and hypochlorite ions promote amino acid degradation and hydration ${ }^{50}$, what corroborates with the mechanism of action performed by WHO $(2016)^{51}$, when affirming that chlorine compounds lead to inhibit actions enzymes, protein denaturation and inactivation of nucleic acids and, therefore, it is recommended as a disinfectant agent for the prevention and control of pandemics related to respiratory infections ${ }^{52}$, such as COVID-19.

Ethyl alcohol would be a second option for disinfecting surfaces, to promote the reduction of disinfectivity in COVID-19. Alcoholic solutions of 60 to $80 \%$ are very effective in promoting protein denaturation ${ }^{53}$, characteristics that explain the efficiency of inactivities $\left(>2 \log _{10}\right)$ against the COVID virus ${ }^{11}$. For solutions with higher alcohol content, where protein denaturation is lower, the efficiency of inactivity ( $\geq 4 \log _{10}$ ) against the COVID virus can be attributed to the increase in the lipophilic characteristic. Even so, alcohol is not considered a good disinfectant agent50 and is not recommended for disinfecting medical and surgical materials, mainly because it does not have sporicidal action and does not penetrate materials rich in proteins ${ }^{54}$.

Therefore, we recommend that hospitals and other environments that provide care to patients with a suspected or confirmed clinical condition of COVID, be disinfected with bleach, using concentrations appropriate to the respective purposes, as mentioned in Table 1 . It is worth mentioning that some countries like Brazil regulate that disinfection measures are adopted three times a week ${ }^{14}$. Some authors suggest that the surfaces of these environments be disinfected twice a day ${ }^{45}$, while other authors suggest four times a day ${ }^{29}$. We understand that the amount of disinfection to be performed daily varies depending on the risk classification and exposure of health agents and patients. Then, considering the experience described for the Department of Oral and Maxillofacial Surgery of Peking University School and Hospital of Stomatology ${ }^{43}$ concerning the control of the pandemic, we suggest that disinfections be carried out daily, at least twice a day, and should be higher, depending on the need.

\section{CONCLUSION}

Due to the pathogenicity and rapid spread of SARS-CoV-2, it is necessary to establish policies to contain COVID-19 in all areas, especially in environments that provide care to suspected or confirmed patients with the virus. Adequate disinfection of these environments is of great importance for the preservation of patients and health agents and contributes in an effective way to promote the decrease of the infectivity of the virus. Among the disinfectants disseminated in the literature, chlorine solutions, such household bleach has the highest cost-benefit and can be applied to most, if not all, needs of health units.

\section{REFERENCES}

1. Cui J, Li F, Shi Z. Origin and evolution of pathogenic coronaviruses. Nat Rev Microbiol. 2019 Mar; 17(3):181-192. doi:. https://doi.org/10.1038/s41579018-0118-9.

2. Wang H, Yuan X, Sun Y, Mao X, Meng C, Tan L, et al. Infectious bronchitis virus entry mainly depends on clathrin mediated endocytosis and requires classical endosomal/lysosomal system. Virology 2019 Fev; 528: 118-136 doi: https://doi. org/10.1016/j.virol.2018.12.012.

3. Fung S, Liu DX. Human Coronavirus: Host-Pathogen Interaction. Annu Rev
Microbiol. 2019 Set; 73: 529-557. doi:10.1146/annurev-micro-020518-115759. 4. Shereen MA, Khan S,Kazmi A, Bashir N, Siddique R. COVID-19 infection: Origin, transmission, and characteristics of human coronaviruses. J Adv Res 2020 Jul; 24: 91-98. doi: https://doi.org/10.1016/j.jare.2020.03.005.

5. World Health Organization. Coronavirus [Internet]. Geneve: WHO 2020[access 2020 Apr 15]. Available from: https://www.who.int/health-topics/ coronavirus\#tab=tab 3 .

6. World Health Organization. Coronavirus disease 2019 (COVID-19) Situation 
Report - 95 [Internet]. Geneve: WHO; 2020[access 2020 Apr 25]. Available from: https://www.who.int/docs/default-source/coronaviruse/situationreports/20200424-sitrep-95-covid-19.pdf?sfvrsn=e8065831_4.

7. World Health Organization. Modes of transmission of virus causing COVID-19: implications for IPC precaution recommendations: Scientific brief [Internet]. Geneve: WHO; 2020. [Access 2020 Apr 15]. Available from: https://www. who.int/publications-detail/modes-of-transmission-of-virus-causing-covid-19implications-for-ipc-precaution-recommendations.

8. Henwood AF. Coronavirus disinfection in histopathology. J Histotechnol. 2020 Mar 1:1-3. doi:. https://doi.org/10.1080/01478885.2020.1734718. [Epub ahead of print].

9. Moriarty LF, Plucinski MM, Marston BJ, Kurbatova EV, Knust B, Murray EL, et al. Public Health Responses to COVID-19 Outbreaks on Cruise Ships Worldwide, February-March 2020. MMWR Morb Mortal Wkly Rep. 2020 Mar; 69(12): 347-352. doi: 10.15585/mmwr.mm6912e3.

10. Otter JA, Donskey C, Yezli S, Douthwaite S, Goldenberg SD, Weber DJ. Transmission of SARS and MERS coronaviruses and influenza virus in healthcare settings: the possible role of dry surface contamination. J Hosp Infect. 2016 Mar; 92(3): 235-50. doi: https://doi.org/10.1016/j.jhin.2015.08.027.

11. Kampf G, Todt D, Pfaender S, Steinmann E. Persistence of coronaviruses on inanimate surfaces and their inactivation with biocidal agents. J Hosp Infect. 2020 Mar; 104(3):246-251. doi: https://doi.org/10.1016/j.jhin.2020.01.022.

12. Xu C, Jin J, Song J, Yang $Y$, Yao $M$, Zhang $Y$ et al. Application of refined management in the prevention and control of coronavirus disease 2019 epidemic in non-isolated areas of a general hospital. Int J Nurs Sci. Epub 2020 Apr . doi: 10.1016/j.jijnss.2020.04.003.

13. Yen M-Y, Schwartz J, King C-C, Lee C-M, Hsueh P-R, Society of Taiwan Longteam Care Infection Prevention and Control. Recommendations for protecting against and mitigating the COVID-19 pandemic in long-term care facilities. J Microbiol Immunol Infect. 2020 Apr. S1684-1182(20)30097-9. doi: https://doi. org/10.1016/j.jmii.2020.04.003.

14. Agência Nacional de Vigilância Sanitária. Orientações para serviços de saúde: medidas de prevenção e controle que devem ser adotadas durante a assistência aos casos suspeitos ou confirmados de infecção pelo novo coronavírus (sarscov-2). Nota Técnica [Internet]. Brasília: ANVISA; 2020 Mar [Access 2020 Apr 15]. Available from: http://portal.anvisa.gov.br/documents/33852/271858/ Nota+T\%C3\%A9cnica+n+04-2020+GVIMS-GGTES-ANVISA/ab598660-3de44f14-8e6f-b9341c196b28.

15. World Health Organization. Infection Prevention and Control guidance for Long-Term Care Facilities in the context of COVID-19 [Internet]. Geneve: WHO; March 2020 [Access 2020 Apr 15]. Available from: https://apps.who.int/iris/ bitstream/handle/10665/331508/WHO-2019-nCoV-IPC_long_term_care2020.1-eng.pdf?sequence $=1 \&$ isAllowed $=y$.

16. World Health Organization. Infection prevention and control during healthcare when COVID-19 is suspected [Internet]. Geneve: WHO; March 2020 [Access 2020 Apr 15]. Available from: https://www.who.int/publications-detail/ infection-prevention-and-control-during-health-care-when-novel-coronavirus(ncov)-infection-is-suspected-20200125.

17. Centers for Disease Control and Prevention. Cleaning and Disinfection for Households-Interim Recommendations for U.S. Households with Suspected or Confirmed Coronavirus Disease 2019 (COVID-19) [Internet]. USA; March 2020 [Access 2020 Apr 15]. Available from: https://www.cdc.gov/coronavirus/2019ncov/prevent-getting-sick/cleaning-disinfection.html.

18. World Health Organization. Water, sanitation, hygiene and waste management for COVID-19 [Internet]. Geneve: WHO; March 2020 [Access 2020 apr 15]. Available from: https://www.who.int/publications-detail/watersanitation-hygiene-and-waste-management-for-covid-19.

19. European Centre for Disease Prevention and Control. Disinfection of environments in healthcare and non health care settings potentially contaminated with SARS-CoV-2 [Internet]. Solna; March 2020 [Access 2020 Apr 15]. Available from: https://www.ecdc.europa.eu/sites/default/files/ documents/Environmental-persistence-of-SARS_CoV_2-virus-Options-forcleaning2020-03-26_0.pdf.

20. Centers for Disease Control and Prevention. Cleaning and Disinfection for Households-Interim Recommendations for U.S. Households with Suspected or Confirmed Coronavirus Disease 2019 (COVID-19) [Internet]. USA: CDC; March 2020 [Access 2020 Apr 15]. Available from: https://www.cdc.gov/ coronavirus/2019-ncov/prevent-getting-sick/cleaning-disinfection.html.

21. Chinese Center for Disease Control and Prevention. Technical guide for disinfecting special places [Internet]. China: CDC; Mar 2020 [Access 2020 Apr 15]. Available from: http://www.chinacdc.cn/jkzt/crb/zl/szkb_11803/ jszl_11815/202003/t20200309_214241.html.

22. World Health Organization. Infection prevention and control of epidemicand pandemic-prone acute respiratory infections in health care [Internet]. Geneva; March 2020 [Access 2020 Apr 15]. Available from: https://apps.who.int/ iris/bitstream/handle/10665/112656/9789241507134_eng.pdf?sequence=1.

23. Kampf G. Potential role of inanimate surfaces for the spread of coronaviruses and their inactivation with disinfectant agents. Infect. Prev. in Practice. 2020 Jun; 2(2): 100044. doi: https://doi.org/10.1016/j.infpip.2020.100044.

24. Weber DJ, Sickbert-Bennett EE, Kanamori H, Rutala WA. New and emerging infectious diseases (Ebola, Middle Eastern respiratory syndrome coronavirus, carbapenem-resistant Enterobacteriaceae, Candida auris): Focus on environmental survival and germicide susceptibility. Am J Infect Control. 2019 Jun; 47: 29-38. doi: https://doi.org/10.1016/j.ajic.2019.03.004

25. Kindermann J, Karbiener M, Leydold SM, Knotzer S, Modrof J, Kreil TR. Virus disinfection for biotechnology applications: Different effectiveness on surface versus in suspension. Biologicals 2020 Mar; 64: 1-9. doi: https://doi. org/10.1016/j.biologicals.2020.02.002.

26. Cavalli A, Marinaro M, Desario C, Corrente M, Camero M, Buonavoglia C. In vitro virucidal activity of sodium hypochlorite against canine parvovirus type 2. Epidemiol Infect. 2018 Nov; 146(15): 2010-2013. doi: 10.1017/ S0950268818002431.

27. Li N, Liu T, Chen H, Liao J, Li H, Luo Q, et al. Management strategies for the burn ward during COVID-19 pandemic. Burns 2020 Abr. doi: https://doi. org/10.1016/j.burns.2020.03.013.

28. Siddharta A, Pfaender S, Vielle NJ, Dijkman R, Friesland M, Becker B, et al. Virucidal Activity of World Health Organization-Recommended Formulations Against Enveloped Viruses, Including Zika, Ebola, and Emerging Coronaviruses. J Infect Dis. 2017 Mar; 215(6): 902-906. doi: 10.1093/infdis/jix046.

29. Chandy PE, Nasir MU, Srinivasan S, Klass D, Nicolaou S, Babu SB. Interventional radiology and COVID-19: evidence-based measures to limit transmission. Diagn Interv Radiol, 2020 Mar. doi 10.5152/dir.2020.20166.

30. Ng Y-M, Peggy PL. Coronavirus disease (COVID-19) prevention: Virtual classroom education for hand hygiene. Nurse Educ Pract. 2020 Abr; 45: 102782. doi: https://doi.org/10.1016/j.nepr.2020.102782.

31. Breidablik HJ, https://www.sciencedirect.com/science/article/pii/ S0195670120301134 - !Lysebo, DE, Johannesse L,Skare Å, Kleiven O, Andersen $J R$. Effects of hand disinfection with alcohol hand rub, ozonized water or soap water - time for reconsideration?. J Hosp Infect. 2020 Mar; S01956701(20)30113-4. doi: https://doi.org/10.1016/j.jhin.2020.03.014.

32. Jones L, Walsh K,Willcox M, Morgan P, Nichols J. The COVID-19 pandemic: Important considerations for contact lens practitioners. Cont Lens Anterior Eye. 2020 Apr. S1367-0484(20)30055-2. doi: https://doi.org/10.1016/j. clae.2020.03.012.

33. Agência Nacional de Vigilancia Sanitária. Procedimento: limpeza e 
desinfeç̧ão de ambientes, equipamentos, utensílios potencialmente contaminados, gerenciamento de resíduos sólidos e efluentes sanitários [Internet]. Brasília: ANVISA; 2020 [Access 2020 Apr 15]. Available from: http:// portal.anvisa.gov.br/documents/219201/5777769/PROCEDIMENTO+01++PLD-Residuo-Efluentes-/54d4b6eb-36a9-45d9-ba8b-49c648a5f375.

34. World Health Organization. Laboratory biosafety guidance related to the novel coronavirus (2019-nCoV) [Internet]. Geneva: WHO; Mar 2020 [Access 2020 Apr 15]. Available from: https://www.who.int/publications-detail/modesof-transmission-of-virus-causing-covid-19-implications-for-ipc-precautionrecommendations.

35. Eggers M. Infectious Disease Management and Control with Povidone lodine. Infect Dis Ther. 2019 Dec; 8(4): 581-593. doi: https://doi.org/10.1007/ s40121-019-00260-x.

36. Kariwa H, Fujii N, Takashima I. Inactivation of SARS coronavirus by means of povidone-iodine, physical conditions and chemical reagents. Dermatology 2006; 212:119-123. doi: https://doi.org/10.1159/000089211.

37. Eggers M, Eickmann M, Zorn J. Rapid and Effective Virucidal Activity of Povidone-lodine Products Against Middle East Respiratory Syndrome Coronavirus (MERS-CoV) and Modified Vaccinia Virus Ankara (MVA). Infect Dis Ther. 2015 Dec; 4(4): 491-501. doi: 10.1007/s40121-015-0091-9.

38. Geller C, Varbanov M, Duval RE. Human Coronaviruses: Insights into Environmental Resistance and Its Influence on the Development of New Antiseptic Strategies. Viruses. 2012 Nov; 4(11): 3044-3068. doi: https://doi. org/10.3390/v4113044.

39. Goyal SM, Chander Y, Yezli S, Otter JA. Evaluating the virucidal efficacy of hydrogen peroxide Vapour. J Hosp Infect. 2014 Apr; 86(4): 255-259. doi: https:// doi.org/10.1016/j.jhin.2014.02.003.

40. Tuladhar E, Terpstra P, Koopmans M, Duizer E. Virucidal efficacy of hydrogen peroxide vapour Disinfection. J Hosp Infect. 2012 Feb; 80(2): 110-115. doi: https://doi.org/10.1016/j.jhin.2011.10.012.

41. Chenga VCC, Wong SC, Kwan GSW, Hui WT, Yuen KY. Disinfection of N95 respirators by ionized hydrogen peroxide during pandemic coronavirus disease 2019 (COVID-19) due to SARS-CoV-2. J Hosp Infect. 2020 Apr. S01956701(20)30178-X. doi: https://doi.org/10.1016/j.jhin.2020.04.003.

42. Rowan NJ, Laffey JG. Challenges and solutions for addressing critical shortage of supply chain for personal and protective equipment (PPE) arising from Coronavirus disease (COVID19) pandemic - Case study from the Republic of Ireland. Sci Total Environ. 2020 Apr; 725: 138532. doi: https://doi. org/10.1016/j.scitotenv.2020.138532.

43. Yang Y, Soh HY, Cai ZG, Peng X, Zhang Y, Guo CB. Experience of Diagnosing and Managing Patients in Oral Maxillofacial Surgery during the Prevention and Control Period of the New Coronavirus Pneumonia. Chin J Dent Res. 2020; 23(1): 57-62. doi: 10.3290/j.cjdr.a44339.

44. Gou SM, Yin T, Xiong JX, Peng T, Li Y, Wu HS. [Treatment of pancreatic diseases and prevention of infection during outbreak of 2019 coronavirus disease]. Zhonghua Wai Ke Za Zhi. 2020 Feb; 58(0):E006. doi: 10.3760/ cma.j.cn112139-20200224-00123.

45. Sleep Disorder Group of Chinese Thoracic Society; Group of Sleep Disordered Breathing, the Committee of Respiratory Diseases of China Association of Medical Equipment. [Expert consensus on sleep study and non-invasive positive airway pressure therapy during the epidemic of coronavirus disease 2019]. Zhonghua Jie He He Hu Xi Za Zhi. 2020 Apr; 43(0): E043. doi: 10.3760/ cma.j.cn112147-20200309-00283.

46. COVID-19 Emergency Response Key Places Protection and Disinfection Technology Team, Chinese Center for Disease Control and Prevention. [Health protection guideline of mobile cabin hospitals during COVID-19 outbreak]. Zhonghua Yu Fang Yi Xue Za Zhi. 2020 Apr; 54(4): 357-359. doi: 10.3760/ cma.j.cn112150-20200217-00121.

47. Zheng C, DU LZ, Fu JF, Shu Q, Chen ZM, Shi LP. [Emergency plan for interhospital transfer of newborns with SARS-CoV-2 infection]. Zhongguo Dang Dai Er Ke Za Zhi. 2020 Mar; 22(3): 226-230. doi: 10.7499/j.issn.1008-8830.2020.03.009

48. Verbeek JH, ljaz S, Mischke C, Ruotsalainen JH, Mäkelä E, Neuvonen K, et al. Personal protective equipment for preventing highly infectious diseases due to exposure to contaminated body fluids in healthcare staff. Cochrane Database Syst Rev. 2016 Apr; 4: CD011621. doi: https://doi.org/10.1002/14651858. CD011621.pub4.

49. Hadis F, Maroufi P, Momen-Heravi M, Dao S, Köse Ş, Ganbarov K, et al. Protection and disinfection policies against SARS-CoV-2 (COVID-19). Infez Med. 2020 Jun; 28(2): 185-191. Ahead of print.

50. Estrela C, Estrela CRA; Barbin EL; Spanó JCE; Marchesan MA; Pécora JD. Mechanism of action of sodium hypochlorite. Braz Dent J 2002; 13(2): 113-117. doi: https://doi.org/10.1590/S0103-64402002000200007.

51. World Health Organization. Decontamination and Reprocessing of Medical Devices for Health-care Facilities [Internet].Geneve: WHO; 2016 [Access $2020 \mathrm{Apr}$ 15]. Available from: https://apps.who.int/iris/bitstream/hand le/10665/250232/9789241549851-eng.pdf?sequence=1.

52. World Health Organization. Infection prevention and control of epidemic and pandemic-prone acute respiratory infections in health care [Internet]. Geneve: WHO; 2014 [Access 2020 Apr 15]. Available from: https://apps.who. int/iris/bitstream/handle/10665/112656/9?sequence=1.

53. World Health Organization. WHO Guidelines on Hand Hygiene in Health Care First: Global Patient Safety Challenge Clean Care is Safer Care [Internet]. Geneve: WHO; 2009 [Access 2020 Apr 15]. Available from: https:// apps.who.int/iris/bitstream/handle/10665/44102/9789241597906_eng. pdf? sequence $=1$ \&isAllowed $=y \& u a=1$.

54. Centers for Disease Control and Prevention. Guideline for Disinfection and Sterilization in Health care Facilities. Update: May 2019 [Internet]. USA: CDC; 2008 [Access 2020 Apr 15]. Available from: https://www.cdc.gov/ infectioncontrol/pdf/guidelines/disinfection-guidelines-H.pdf.

\section{Como citar este artigo/How to cite this article:}

